\title{
Karakteristik Morfologi dan Indeks Ekologi Bulu Babi (Echinoidea) di Perairan Desa Wawama Kabupaten Pulau Morotai
}

\author{
Morphological Characteristics and Ecological Index Sea Urchins (Echinoidea) \\ in Wawama Village Water Morotai Island District
}

\author{
Djainudin Alwi $^{1 *}$, Sandra Hi. Muhammad ${ }^{1}$ dan Irwanto Tae ${ }^{1}$ \\ ${ }^{1}$ Program Studi Ilmu Kelautan, FPIK UNIPAS Morotai, 97771, Indonesia \\ *Korespondensi: djainudinalwi@gmail.com
}

\begin{abstract}
ABSTRAK
Masyarakat Desa Wawama Kabupaten Pulau Morotai memanfaatkan bulu babi sebagai bahan makanan, namun pengetahuan mengenai bulu babi sendiri hanyalah semata-mata sebagai bahan makanan yang bernilai ekonomis. Sedangkan aspek morfologi dan ekologi sampai sejauh ini belum diketahui. Penelitian ini bertujuan mempelajari karateristik morfologi dan menganalisis indeks ekologi bulu babi (Echinoidea). Penelitian ini dilaksanakan pada bulan November-Desember 2019 bertempat di Desa Wawama Kecamatan Morotai Selatan Kabupaten Pulau Morotai. Hasil penelitian menunjukan bahwa ada perbedaan karateristik morfologi dari jenis bulu babi yang ditemukan dilokasi penelitian baik dari bentuk tubuh, warna maupun organ lainnya. Hasil analisis indeks ekologi untuk nilai kepadatan bulu babi terlihat bervariasi, dimana jenis Diadema setosum memiliki nilai tertinggi disemua stasiun penelitian. Keanekaragaman jenis pada ke tiga stasiun dengan kisaran nilai 0,658-1,032-1,336 dengan nilai rata-rata sebesar 1,009, sesuai pada kriteria keanekaragaman jenis ( $\left.\mathrm{H}^{\prime}\right)$ pada analisis Shannon Winner kategori sedang. Indeks kemerataan (E) kategori cukup merata karena nilai yang diperoleh berkisar antara 0,329-0,346 rata-rata sebesar 0,336 dan indeks dominasi (C) dinyatakan tidak ada spesies yang mendominasi karena nilai yang diperoleh berkisar antara 0,275-0,535 dengan nilai rata-rata dari tiga stasiun sebesar 0,396.
\end{abstract}

Kata kunci : Morfologi, ekologi; bulu babi, Kabupaten Pulau Morotai

\begin{abstract}
The people of Wawama Village, Morotai Island Regency, use sea urchins as food, but the knowledge of sea urchins themselves is a food that has economic value. While the morphological and ecological aspects so far have not been known. This aims to study the morphological characteristics and analyze the ecological index of sea urchins. This research was conducted in November-December 2019 in the Village of Wawama, South Morotai District, Pulau Morotai District. The results showed that there were differences in the morphological characteristics of the types of sea urchins found in the study location both from body shape, color and external organs. The results of the ecological index analysis for the value of the density of sea urchins look varied, where the type of Diadema setosum has the highest value in all research stations. Species diversity at the three stations with a range of values from 0.658 to 1.032-1.336 with an average value of 1.009 , according to the species diversity criteria ( $\left.\mathrm{H}^{\prime}\right)$ in the medium category Shannon Winner analysis. Evenness index (E) category is quite evenly distributed because the values obtained ranged from 0.329 to 0.346 on average by 0.336 and the dominance index
\end{abstract}


(C) was declared to be no species dominance because the values obtained ranged from 0.275 to 0.535 with the mean of the three stations amounted to 0.396 .

Key words: Morphology; ecology; sea urchins, Morotai island district

\section{PENDAHULUAN}

Landak laut atau juga dikenal dengan bulu babi (Echinoidea) umumnya hidup di daerah batu karang, lamun, dan juga pasir. Bulu babi hidup berkoloni yang berfungsi agar dapat mempertahankan diri dan ada juga yang hidup menyendiri yang membuat bulu babi rentan terhadap predator. Keberadaan bulu babi pada suatu ekosistem tidak lepas juga dari pengaruh faktor fisika kimia pada lingkungan tersebut. Bulu babi memiliki fisik pertahanan (duri) dan yang membuat mereka cocok untuk bertahan dan melindungi diri dari organisme laut seperti moluska, udang, kepiting, polychaetes (cacing anelida), copepods (crustacea kecil), dan ikan, (Ayyagari dan Kondamudi, 2014).

Secara ekonomi gonad bulu babi dapat dikonsumsi sehingga memiliki nilai jual yang cukup tinggi. Bulu babi merupakan salah satu sumber daya perairan yang mempunyai potensi untuk dikembangkan sebagai penambah keanekaragaman protein hewani (Rachmawaty, 2004). Oleh masyarakat yang tinggal di daerah pesisir lebih dikenal dengan nama "duri babi" yang merupakan salah satu dari sekian jenis makrobentos dari kelas Echinoidea yang dapat mencapai ukuran diameter cangkang $163 \mathrm{~mm}$ dan mencapai berat 200 gram (Radjab, 2001).

Manfaat ekologis bulu babi beragam termasuk diantaranya adalah sebagai tempat berlindung beberapa jenis ikan tertentu, makanan beberapa jenis ikan, organisme penentu berperan dalam berbagai interaksi dengan biota laut lain. Merupakan faktor penentu kelimpahan dan sebaran tumbuhan laut perairan dangkal. Organisme ini menjadi spesies utama yang mengontrol struktur komunitas ganggang laut dan atas rusaknya komunitas lamun di beberapa daerah pantai tropika dan subtropika (Suryanti dan Ruswahyuni, 2014). Anwar dkk, (2015) mengemukakan bahwa secara morfologi bulu babi merupakan hewan yang unik karena memiliki duri pada seluruh bagian tubuhnya yang berfungsi sebagai alat gerak maupun pelindung diri dari serangan predator.

Pengetahuan tentang karateristik morfologi penting untuk dipelajari sehingga dapat dibedakan mana jenis yang bernilai ekonomis dan tidak bernilai ekonomis karena tidak semua jenis bulu babi dapat dikonsumsi, hal ini lakukan untuk menghindari terjadinya eksploitasi berlebihan oleh masyarakat. Sedangkan indeks ekologi berkaitan dengan nilai yang mengambarkan kestabilan organisme dalam suatu komunitas dengan lingkungannya. Ardi, (2002) berpendapat bahwa faktor lingkungan abiotik dan biotik sangat bepengaruh terhadap interaksi spesies serta pola siklus hidup dari masing-masing spesies dalam komunitas dengan demikian, maka pengetahuan tentang indeks ekologi sangat penting untuk pelajari.

Masyarakat Desa Wawama Kabupaten Pulau Morotai memanfaatkan bulu babi sebagai bahan makanan, namun pengetahuan mengenai bulu babi sendiri hanyalah semata-mata sebagai bahan makanan yang bernilai ekonomis. Sedangkan aspek morfologi dan ekologi sampai sejauh ini belum diketahui. Penelitian ini dilakukan bertujuan untuk mempelajari karakteristik morfologi dan indeks ekologi bulu babi. Hasil penelitian ini diharapkan dapat memberikan informasi dasar bagi pihak-pihak terkait aspek morfologi serta kondisi ekologis bulu babi di perairan Desa Wawama Kabupaten Pulau Morotai. 


\section{METODE PENELITIAN}

\section{Alat dan bahan}

Alat dan bahan yang digunakan dalam penelitian ini adalah kuadrat $1 \times 1$ $\mathrm{m}$, meteran roll, GPS (GARMIN 64s), Hand Refraktometer (Portable refraktometer), thermometer (Oxygen Meter), dan pengukur $\mathrm{pH}$ air (Hanna instrument), dan sampel bulu babi.

Penelitian ini ditetapkan sebanyak 3 stasiun tiap stasiun terdiri dari 3 (tiga) transek sehingga total ada 9 transek. Pengambilan sampel bulu babi menggunakan metode transek kuadrat. Pengambilan sampel dimulai dari pemasangan transek dengan menggunakan meteran rol yang ditarik tegak lurus kearah laut sepanjang 100 meter pada saat air laut surut terendah. Penempatan mulai dari meteran nol dengan menggunakan kuadrat berukuran 1x1 meter sebanyak 10 kali penempatan, jarak antar kuadrat satu dengan berikutnya yaitu 10 meter. Untuk lebih jelas mengenai metode pengambilan data, dapat dilihat pada (Gambar 1).

Sampel bulu babi yang terdapat pada kuadrat kemudian dihitung dan diambil satu yang mewakili setiap jenisnya dan dimasukan kedalam kantong plastik yang telah diberi lebel dan kemudian diidentifikasi mengunakan panduan identifikasi menurut (Setiawan 2010). Sedangkan indentifikasi morfologi bulu babi yang ditemukan dilokasi penelitian menggunakan panduan identifikasi menurut Radjab (2001).

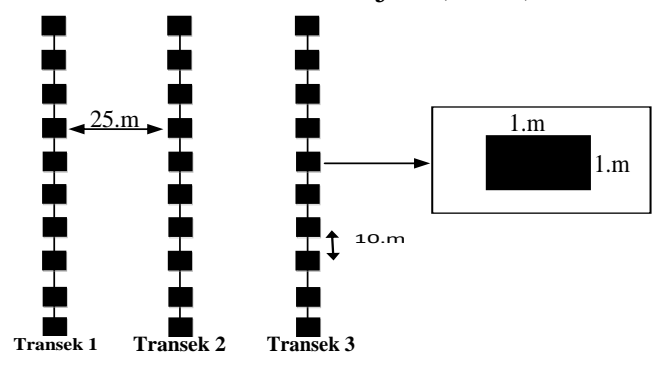

Gambar 1. Sketsa pengambilan data (Metode transek kuadrat)
Sebagai data penunjang dilakukan pengukuran parameter lingkungan meliputi, suhu, salinitas, $\mathrm{pH}$, dan substrat.

\section{Analisis Data}

Hasil identifikasi jenis dan morfologi bulu babi ditampilkan dalam bentuk gambar kemudian dijelaskan secara deskriptif. Sedangkan analisis indeks ekologi bulu babi meliputi; Kepadatan (D), keanekaragaman jenis $\left(\mathrm{H}^{\prime}\right)$, dominansi (C) dan indeks kemerataan (E) menggunakan model matematis sebagai berikut :

1. Kepadatan (Krebs, 1985)

$$
\mathrm{D}=\frac{X}{A}
$$

Dimana :

$$
\begin{aligned}
& \mathrm{D}=\text { Kepadatan setiap jenis }\left(\mathrm{Ind} / \mathrm{m}^{2}\right) \\
& \mathrm{X}=\mathrm{Jumlah} \text { individu tiap jenis } \\
& \left(\mathrm{Ind} / \mathrm{m}^{2}\right) \\
& \mathrm{A}=\text { Luas areal yang terukur dengan } \\
& \text { kuadrat }\left(\mathrm{m}^{2}\right)
\end{aligned}
$$

\section{Keanekaragaman Jenis}

Untuk menghitung besarnya keanekaragaman jenis digunakan metode Shannon dan Weinner (Ludwig dan Reynolds, 1988), sebagai berikut :

$$
H^{\prime}=\sum_{n=1}^{S}\left(\frac{n i}{N} \operatorname{Ln} \frac{n i}{N}\right)
$$

Keterangan :

$\mathrm{H}$ : Keanekaragaman Jenis

ni : Jumlah individu jenis-i

$\mathrm{N}$ : Jumlah seluruh individu

Kriteria :

$\mathrm{H}^{\prime}<1=$ Keanekaragaman Jenis

Rendah

$1 \leq \mathrm{H}^{\prime} \leq 3=$ Keanekaragaman Jenis Sedang

$\mathrm{H}^{\prime}>3$ = Keanekaragaman Jenis Tinggi

3. Indeks Dominasi

$$
\text { Untuk menghitung indeks }
$$

dominasi digunakan formula

(Odum,1996), sebagai berikut: 


$$
C=\sum\left(\frac{n i}{N}\right)
$$

Keterangan:

$\mathrm{C}$ : Indeks Dominansi

ni : Jumlah individu tiap jenis

$\mathrm{N}$ : Jumlah individu seluruh jenis

Dengan Kriteria:

Nilai C berkisar 0-1, Jika C mendekati 0 berrarti tidak ada spesies yang mendominasi dan apabila nilai $\mathrm{C}$ mendekati 1 adanya salah satu spesies yang mendominasi.

4. Indeks Kemerataan (Wibisono 2005)

$$
\mathrm{E}=\frac{\mathrm{H}^{\prime}}{\operatorname{Hmax}}
$$

Keterangan:

$$
\begin{aligned}
& \mathrm{E}=\text { Indeks kemerataan } \\
& \mathrm{H}^{\prime}=\text { Keanekaragaman Jenis } \\
& \mathrm{H}_{\max }=\text { Ln S } \\
& \mathrm{S} \quad=\text { Jumlah Taksa }
\end{aligned}
$$

Dengan kriteria penyebaran jenis:

$$
\begin{aligned}
& >0,81=\text { sangat merata } \\
& 0,61-0,80=\text { lebih merata } \\
& 0,41-0,60=\text { merata } \\
& 0,21-0,40=\text { cukup merata } \\
& <0,21=\text { tidak merata }
\end{aligned}
$$

\begin{tabular}{|c|c|c|c|}
\hline \multirow{2}{*}{ Parameter } & \multicolumn{3}{|c|}{ Stasiun } \\
\hline & I & II & III \\
\hline Salinitas & $33 \%$ & $34 \%$ & $34 \%$ \\
\hline $\mathrm{pH}$ & 7 & 8 & 8 \\
\hline Suhu ${ }^{\circ} \mathrm{C}$ & $32^{\circ} \mathrm{C}$ & $33^{\circ} \mathrm{C}$ & $33^{\circ} \mathrm{C}$ \\
\hline Substrat & Berpasir & Berlumpur & $\begin{array}{c}\text { Patahan } \\
\text { Karang }\end{array}$ \\
\hline
\end{tabular}

\section{HASIL DAN PEMBAHASAN}

\section{Parameter Lingkungan}

Hasil pengukuran parameter lingkungan dilokasi penelitian meliputi; salinitas, suhu, $\mathrm{pH}$, dan substrat disajikan pada Tabel 1.

Tabel 1. Pengukuran parameter Lingkungan

\section{Suhu}

Hasil pengukuran suhu diperairan Desa Wawama di ketiga stasiun penelitian berkisar antara $32-33{ }^{\circ} \mathrm{C}$. Budiman dkk, (2014) menyatakan bahwa suhu 28- $32 \dot{C}$ termasuk kondisi baik bagi bulu babi untuk hidup dan berkembang biak. Berdasarkan peryataan tersebut dapat disimpulkan bahwa nilai kisaran suhu yang diperoleh dilokasi penelitian tersebut mampu mendukung kehidupan bulu babi.

\section{pH}

Derajat keasaman $(\mathrm{pH})$ air laut cendrung berada dalam keseimbangan karena ekosistem air laut seperti terumbu karang dan lamun yang merupakan habitat dari Bulu babi mempunyai kapasitas penyangga yang mampu mempertahankan nilai $\mathrm{pH}$. Menurut Odum (1971) bahwa air laut merupakan sistem penyangga yang sangat luas dengan $\mathrm{pH}$ relatif stabil sebesar 7,0-8,5. Hasil pengukuran $\mathrm{pH}$ air di perairan Desa Wawama masih tergolong normal.

\section{Salinitas}

Salinitas $33 \%$ - $34 \%$ merupakan jumlah total garam dari material padat termasuk garam NaCI yang terkandung dalam suatu kilogram air laut. Salinitas menggambarkan padatan total dalam air, setelah semua karbon dikonversi menjadi oksida, semua bromide dan iodida digantikan oleh klorida, dan semua bahan organik telah dioksidasi (Nontji 2005). Avertebrata sangat baik pada salinitas 30 $35 \mathrm{ppm}$, pengaruh air tawar dan air hujan menyebabkan pertumbuhan avertebrata tidak maksimal.

\section{Substrat}

Substrat perairan pada lokasi penelitian berupa berpasir, berlumpur dan patahan karang bulu babi secara umum ditemukan pada habitat rataan terumbu karang, berpasir berbatu, batu berpasir. Budiman dkk, (2014) menyatakan bahwa pada daerah terumbu karang terdapat kepadatan yang tinggi bulu babi. 
Berdasarkan pernyataan tersebut dapat disimpulkan bahwa substrat yang berada pada lokasi penelitian tersebut mendukung kehidupan bulu babi.

\section{Jenis Bulu babi yang ditemukan}

Terdapat 4 (empat) jenis bulu babi yang ditemukan dilokasi penelitian terdiri dari 2 (dua) family. yaitu family Diadematidae sebanyak 1 (satu) jenis dan family Echinometridae 3 (tiga) jenis selengkapnya dilihat pada Tabel 2.

\section{Klasifikasi}

$\begin{array}{ll}\text { 1) Kingdom } & \text { : Animalia } \\ \text { Phyllum } & : \text { Echinodermata } \\ \text { Class } & : \text { Echinodea } \\ \text { Ordo } & \text { : Cidaroidea } \\ \text { Family } & \text { : Diadematidae } \\ \text { Genus } & : \text { Diadema } \\ \text { Spesies } & : \text { Diadema setosum } \\ & \\ \text { 2) Kingdom } & : \text { Animalia } \\ \text { Phylum } & : \text { Echinodermata } \\ \text { Class } & : \text { Echinoidea } \\ \text { Ordo } & : \text { Echinoida } \\ \text { Family } & : \text { Echinometridae } \\ \text { Genus } & : \text { Echinometra } \\ \text { Spesies } & : \text { Echinometra viridis } \\ & \\ \text { 3) Kingdom } & : \text { Animalia } \\ \text { Phylum } & : \text { Echinodermata } \\ \text { Class } & : \text { Echinoidea } \\ \text { Ordo } & : \text { Echinoida } \\ \text { Family } & : \text { Echinometraidae } \\ \text { Genus } & : \text { Echinometra } \\ \text { Spesies } & : \text { Echinometra mathaei }\end{array}$

4) Kingdom : Animalia

Phylum : Echinodermata

Class : Echinoidea

Ordo : Echinoida

Family : Echinothridae

Genus : Echinothrix

Spesies : Echinothrix calamaris

\section{Karaterisitik Morfologi}

1) Jenis Diadema setosum

Berbeda dengan bintang laut dan bintang ular, bulu babi tidak memiliki lengan. Tubuh bulu babi berbentuk bulat seperti bola dengan cangkang yang keras berkapur dan dipenuhi duri-duri. Duri-duri terletak berderet dalam garisgaris membujur dan dapat digerakkan. Mulut terletak di bawah menghadap ke bawah dan anus terletak di atas bagian ke atas di puncak cangkang yang membulat.

Diadema setosum memiliki ciri-ciri berwarna hitam dengan dari-duri berwarna hitam yang memanjang keatas untuk pertahanan diri sedangkan bagian bawah sebagai alat pergerakan. Memiliki 5 titik putih pada bagian atas dan terletak di antara segmen setiap 1 titik putih. Menurut Musfirah (2018) Diadema setosum memilik ciri khas berupa memiliki duri-duri yang panjang, tajam dan rapuh disekujur tubuhnya, memiliki tubuh bulat, warna berwarna hitam pekat, memiliki Gonopore sebabnyak 5 buah serta sangat jelas seperti mengkilap atau menyala. Habitat di karang, alga, pasir dan lamun, dimana mereka dapat melekatkan kaki ambulakral mereka.

Tabel 2. Jenis bulu babi yang ditemukan

\begin{tabular}{cll}
\hline Family & \multicolumn{1}{c}{ Genus } & \multicolumn{1}{c}{ Jenis } \\
\hline Deadematidae & Diadema & Diadema setosum \\
& Echinometra & Echinometra virdis \\
Echinometridae & Echinometra & Echinometra mathaei \\
& Echinotrix & Echinotrix calamaris \\
\hline
\end{tabular}




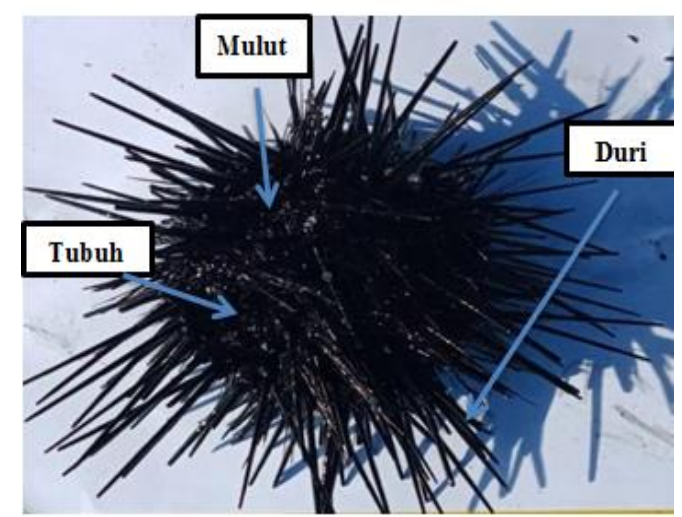

Gambar 2. Diadema setosum

\section{2) Jenis Echinometra viridis}

Echinometra viridis merupakan spesimen ini tubuhnya berbentuk oval, berwarna hitam pekat, duri tidak terlalu panjang seperti family diadematidae, berduri tebal runcing dan jaraknya rapatrapat dengan memiliki mulut dipusat permukaan oral. Kastawi (2003) menjelaskan tubuh Echinometra viridis biasanya berbentuk bola seperti mangkuk, oval atau bentuk jantung. Tubuh tertutup cangkang endoskeleton dan dari lempeng duri kalkareus yang rapat, tertutup oleh spina yang dapat digerakkan memiliki, podia atau kaki tabung yang berfungsi sebagai pergerakan, mulut terletak di pusat permukaan oral.

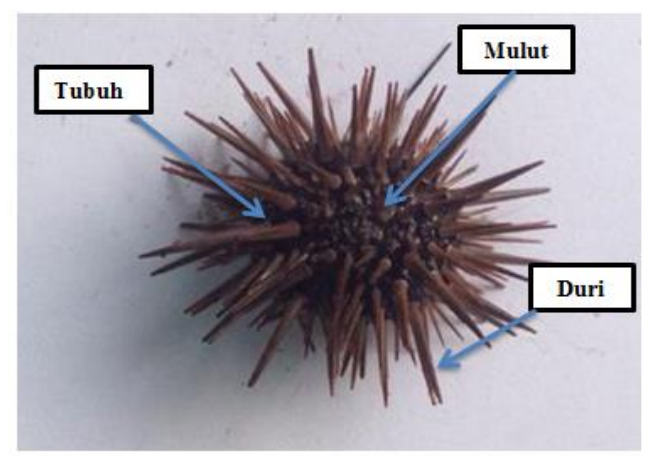

Gambar 3. Echinometra viridis

\section{3) Jenis Echinometra mathei}

Echinometra mathei merupakan bulu babi yang masuk kedalam pencil urcin (bulu babi pensil), jenis memiliki ciri-ciri berupa duri yang besar padat Panjang dengan ujung runcing, durinya berwarna coklat pada pangkal duri berwarna putih serta cangkangnya berwarna hitam kemerahan. Habitatnya di daerah karang pada perairan yang dangkal.

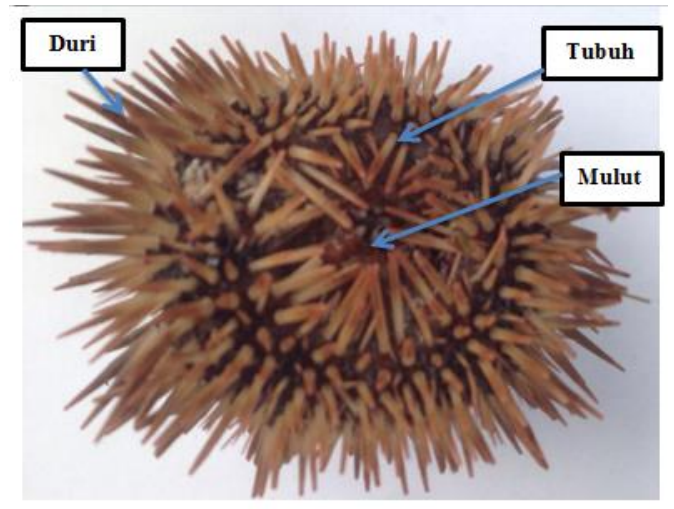

Gambar 4. Echinometra mathaei

4) Jenis Echinotrix calamaris

Echinotrix calamaris memiliki tubuh berwarna putih polos dan coklat belang-belang, memiliki duri yang tebal yang berfungsi sebagai alat gerak dan perlindungan dari predator. Arhas dkk, (2015) menjelaskan bahwa Echinotrix calamaris termasuk dalam famili Diadematidae. Namun, jenis memiliki duri yang ganda (double spined urchin). Ciri-cri tubuh hewan ini memiliki rangka yang keras. Echinothrix calamaris memiliki warna yang bervariasi yaitu: warna coklat dengan berbentuk bintang, warna putih dan belang pada durinya. Habitatnya di terumbu karang dan rubble (pecahan karang).

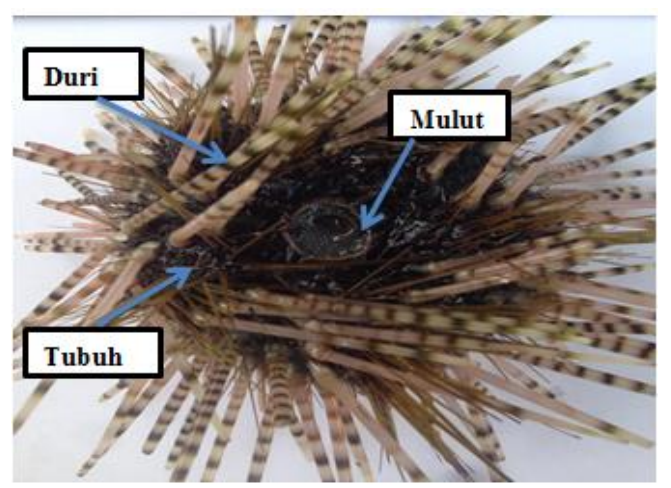

Gambar 5. Echinotrix calamaris

\section{Kepadatan Jenis (D)}

Pada Gambar 6 terlihat bahwa nilai kepadatan tertinggi bulu babi yang 
ditemukan pada stasiun I yaitu jenis Diadema sitosum sebesar 3,200 ( $\left.\mathrm{Ind} / \mathrm{m}^{2}\right)$, dan yang terendah dari jenis Echinometra mathei dengan nilai 1,867 (Ind/ $\left./ \mathrm{m}^{2}\right)$.

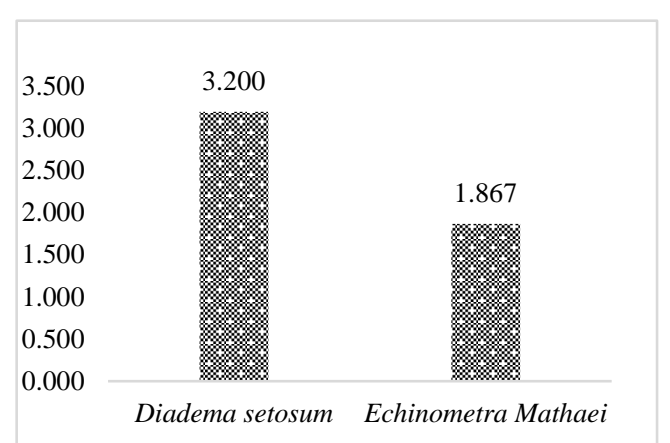

Gambar 6. Nilai Kepadatan $\left(\mathrm{Ind} / \mathrm{m}^{2}\right)$ Bulu babi Pada Stasiun I

Nilai kepadatan tertinggi bulu babi yang ditemukan pada stasiun II (Gambar 7) masih ditempati oleh jenis Diadema setosum sebesar 2,600 ( $\left.\mathrm{Ind} / \mathrm{m}^{2}\right)$, sedangkan yang paling terendah yaitu jenis Echinotrix calamaris sebesar 1,003 (Ind $\left./ \mathrm{m}^{2}\right)$.

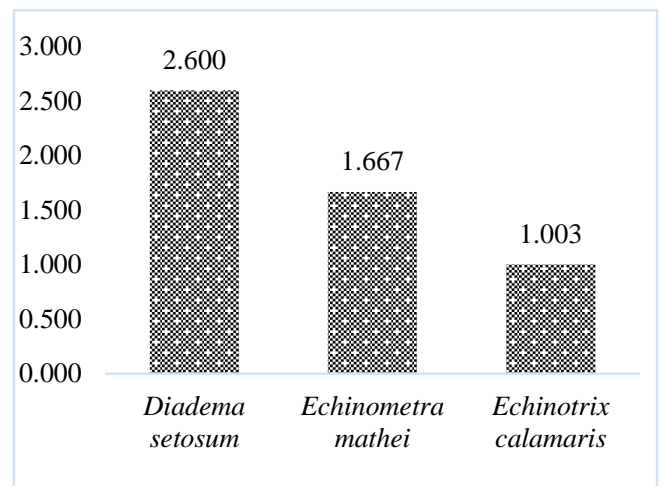

Gambar 7. Nilai Kepadatan $\left(\mathrm{Ind} / \mathrm{m}^{2}\right)$ Bulu babi Pada Stasiun II

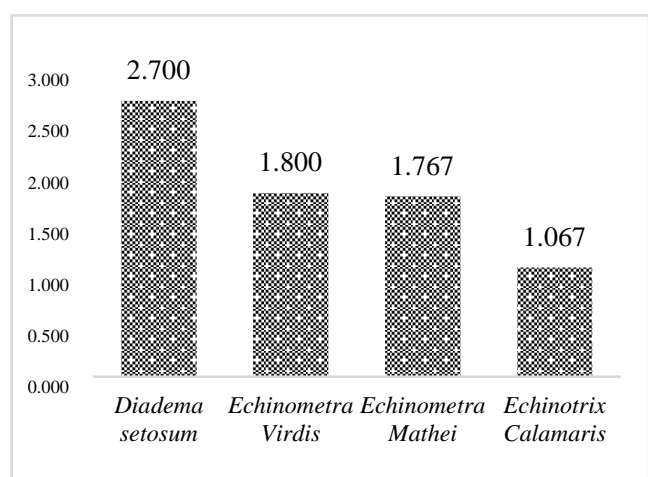

Gambar 8. Nilai Kepadatan $\left(\mathrm{Ind} / \mathrm{m}^{2}\right)$ Bulu babi Pada Stasiun III
Pada stasiun III (gambar 8) jenis Diadema setosum masih merupakan jenis yang memilki nilai kepadatan tertinggi sebesar 2,700 ( $\left.\mathrm{Ind} / \mathrm{m}^{2}\right)$, dan Echinotrix calamaris merupakan jenis memiliki nilai kepadatan terendah hanya sebesar 1,067 (Ind $\left./ \mathrm{m}^{2}\right)$.

Berdasarkan hasil analisis di ketiga stasiun penelitian (Gambar 6, 7 dan 8) nilai kepadatan bulu babi terlihat bervariasi, dimana jenis Diadema setosum memiliki nilai tertinggi disemua stasiun penelitian menandakan bahwa jenis ini mampu beradaptasi terhadap perubahan lingkungan dan kesesuain habitat. Hal ini sejalan dengan pendapat Aziz, (1993) bahwa tinggi rendahnya nilai kepadatan pada jenis Diadema setosum ini lebih disebabkan oleh kemampuan atau daya adaptasi dari jenis tersebut. Hasil penelitian dari Musfirah, (2018) menemukan bahwa kepadatan jenis Diadema setosum diperairan Barrang Lompo Sulawesi Selatan sangat tinggi karena jenis ini kebanyakan hidup di substrat keras dan berpasir dan hidup pada ekosistem terumbu karang dan lamun. Kehadiran populasi jenis Diadema setosum penting bagi terumbu karang sebagai penyeimbang. Kesetimbangan populasi Diadema akan menjaga kesetimbangan populasi alga dan karang (Suryanti dan A'in, 2013).

Selain itu jenis Diadema setosum merupakan jenis bulu babi yang jarang di konsumsi oleh masyarakat sehingga populasinya meningkat. Bulu babi yang biasa dimanfaatkan sebagai bahan makanan yaitu dari genus Tripneustes. Diduga jenis ini tidak ditemukan dilokasi penelitian karena dimanfaatkan oleh masyarakat sekitar.

\section{Indeks Ekologi}

Hasil analisis Indeks ekologi bulu babi yang ditemukan dilokasi penelitian, meliputi, keanekaragaman jenis (H'), dominansi (C), dan kemerataan (E) dapat di lihat pada Tabel 3. 
Tabel 3. Hasil analisis indeks ekologi bulu babi dilokasi penelitian

\begin{tabular}{cccccl}
\hline \multirow{2}{*}{ Indeks Ekologi } & \multicolumn{3}{c}{ Stasiun } & \multirow{2}{*}{ Rerata } & \multicolumn{2}{c}{ Kategori } \\
\cline { 2 - 5 } & I & II & III & & \\
\hline H' & 0,658 & 1,032 & 1,336 & 1,009 & Sedang \\
$\mathbf{E}$ & 0,329 & 0,346 & 0,334 & 0,336 & Cukup Merata \\
$\mathbf{C}$ & 0,535 & 0,378 & 0,275 & 0,396 & Tidak ada jenis yang mendominasi \\
\hline
\end{tabular}

Analisis indeks ekologi ditunjukan pada tabel 2 hasil perhitungan indeks keanekaragaman jenis (H') tertinggi terdapat di stasiun III dengan nilai 1,336 dan terendah 0,658 pada stasiun I, selanjutnya indeks kemerataan (E) tertinggi pada stasiun II dengan nilai 0,346 dan terendah 0,329 pada stasiun I. Sedangkan indeks dominansi (C) tertinggi pada stasiun II dengan nilai 0,378 dan terendah pada stasiun I dengan nilai sebesar 0,535.

Berdasarkan hasil analisis indeks keanekaragaman jenis bulu babi dilokasi penelitian bahwa nilai indeks keanekaragaman jenis ( $\left.\mathrm{H}^{\prime}\right)$ tergolong kategori sedang dengan kisaran 0,6581,336 dengan nilai rata-rata dari ketiga stasiun sebesar 1,009 sesuai dengan kriteria keanekaragaman Shanon winner jika $1 \leq \mathrm{H}^{\prime} \leq 3$ maka, keanekaragaman jenis sedang.

Anwar dkk, (2015) menyebutkan bahwa suatu komunitas dikatakan mempunyai keanekaragaman jenis tinggi jika komunitas itu disusun oleh banyak spesies (jenis) dengan kelimpahan spesies yang sama atau hampir sama. Sebaliknya jika komunitas itu disusun oleh sangat sedikit spesies, dan jika hanya sedikit saja spesies yang dominan, maka keanekaragaman jenisnya rendah. Sejalan dengan itu menurut Odum (1996) bahwa spesies yang mempunyai keanekaraga-man jenis tinggi menujukan bahwa spesies ini memiliki kemampuan menempati ruang yang lebih luas sehingga kesempatan untuk berkembang biak lebih banyak. Hal senada juga dikemukaan oleh Alwi dkk, (2020) bahwasanya suatu komunitas dikatakan memiliki keanekaragaman tinggi jika tidak ada kompetisi antar jenis, adanya ketersediaan makanan yang cukup dan kondisi lingkungan yang mendukung.

Indeks kemerataan (E) pada ketiga stasiun penelitian berdasarkan hasil analisis tergolong cukup merata karena nilai yang diperoleh berkisar antara 0,329-0,346 dengan nilai rata-rata sebesar 0,336 . Hal ini sesuai dengan kriteria menurut Wibisono (2005) jika nilai dominasi berkisar antara 0,21-0,40 maka penyebaran jenis cukup merata. Mattewakkang (2013) mengemukakan bahwa kemerataan hewan bentos dalam suatu perairan dapat diketahui dari indeks keseragamannya. Semakin kecil nilai indeks keseragaman organisme maka penyebaran individu tiap jenis tidak sama, ada kecenderungan didominasi oleh jenis tertentu.

Dominansi (C) mengambarkan kecenderungan jenis tertentu pada suatu komunitas. Hasil analisis indeks dominasi bulu babi dilokasi penelitian dinyatakan tidak ada spesies yang mendominasi karena nilai yang diperoleh berkisar antara 0,275-0,535 dengan rata-rata dari tiga stasiun sebesar 0,396. Sesuai dengan kriteria dominasi menurut Odum (1996) jika $\mathrm{C}$ mendekati 0 berarti tidak ada spesies yang mendominasi dan apabila $\mathrm{C}$ mendekati 1 berarti ada salah satu spesies yang mendominasi. Indeks dominasi (C) berhubungan dengan Kemertaan (E), jika semakin tinggi nilai kemerataan, maka tidak ada spesies yang mendominasi pada suatu komunitas, hal ini dikarenakan pembagian individu pada semua jenis bulu babi merata dilokasi penelitian. Selain itu juga tingginya nilai kemerataan bulu babi dilokasi penelitian menunjukan bahwa tidak ada persaingan yang berarti antara spesies dalam hal ruang maupun makanan, dan dapat dipastikan juga 
bahwa secara ekologi keberadaan komunitas bulu babi dilokasi penelitian masih dalam kondisi stabil. Mattewakkang (2013) berpendapat yang sama bahwa jika suatu komunitas terdapat spesies tertentu yang mendominasi, maka keseimbangan komunitas akan menjadi tidak stabil dan akan mempengaruhi keanekaragaman dan keseragaman.

\section{KESIMPULAN}

Hasil penelitian menunjukan bahwa ada perbedaan karateristik morfologi dari jenis bulu babi yang ditemukan dilokasi penelitian baik dari bentuk tubuh, warna maupun organ lainnya. Hasil analisis indeks ekologi untuk nilai kepadatan bulu babi terlihat bervariasi, dimana jenis Diadema setosum memiliki nilai tertinggi disemua stasiun penelitian. Keanekaragaman jenis pada ke tiga stasiun dengan kisaran nilai 0,658-1,032-1,336 dengan nilai rata-rata sebesar 1,009 , sesuai pada kriteria keanekaragaman jenis $\left(\mathrm{H}^{\prime}\right)$ pada analisis Shannon Winner kategori sedang. Indeks kemerataan (E) tergolong kategori cukup merata karena nilai yang diperoleh berkisar antara 0,329-0,346 dengan nilai rata-rata sebesar 0,336 . Sedangkan indeks dominasi (C) dinyatakan tidak ada spesies yang mendominasi karena nilai yang diperoleh berkisar antara 0,275-0,535 dengan nilai rata-rata dari tiga stasiun sebesar 0,396.

\section{DAFTAR PUSTAKA}

Anwar C., Muzahar dan Karlina, I. 2015. Bioekologi Bulu Babi (Echinoidea) di Perairan Laut Teluk Dalam Desa Malang Rapat Kecamatan Gunung Kijang Kabupaten Bintan. Jurusan Ilmu Kelautan Fakultas Ilmu Kelautan dan Perikanan, Universitas Maritim Raja Ali Haji.

Ardi, 2002. Pemanfaatan Makrozoobenthos Sebagai Indikator Kualitas Perairan Pesisir. Pascasarjana Institut Perta-nian Bogor

Arhas, F.R, Mahdi N, dan Kamal S. 2015 Struktur Komunitas Dan
Karakteristik Bulu Babi (Echinoidea) Di Zona Sublitoral Perairan Iboh Kecamatan Sukakarya Kota Sabang. Prosiding Seminar Nasional Biotik 2015 ISBN: 978-602-18962-5-9 233. Program Studi Pendidikan Biologi Fakultas Tarbiyah dan Keguruan UIN Ar-Raniry.

Ayyagari, A, and Kondamudi, R, B. 2014. Ecological Significance of the Association between stomopneustes Variolaris (Echi-noidea) and Lumbrinerislatreilli (polychaeta) from Visakhapatnam Coast India. Jurnal of Marine Biologi. India

Aziz A. 1993. Beberapa catatan tentang perikanan bulu babi. Oseana 18(2): 65-75

Budiman, C.C., D.Y Katili., M.L.D. Langoy, dan P.V. Maabat. 2014. Keanekaragaman Echinodermata di Pantai Basaan Satu Kecamatan Ratatotok Sulawesi Utara. Jurnal MIPA UNSRAT Online 3(2): 97101.

D. Alwi, S.H Muhammad, H.H, Musadik. 2020. Struktur Komunitas Teripang (Holotroidea) di Perairan Juanga Kabupaten Pulau Morotai. Jurnal Ilmiah Wahana Pendidikan. Vol. 6 No.1. e-ISSN: 2089-5364 p-ISSN: 2622-8327. Hal 41-48

Kastawi, 2003. Zoologi avertebrata, Jurusan Biologi Fakultas Matematika dan Ilmu Pengetahuan Alam Universitas Negeri Malang.

Krebs, C. J., 1985. Ecology. The Experimental Analysis of Distribution and Abundance. New York: Harper Collins, Publisher, p. 894

Ludwig, J. A. and J. F. Reynolds. 1988. Statistical Ecology a Rimer on Methode and Computing. A Willey Interscience Publication, Canada.

Mattewakkang. 2013. Inventarisasi Makrozoobentos pada berbagai Jenis Lamun di Pulau Binebatang. Skripsi. Ilmu kelautan. Universitas Hasanudin. Makasar. 
Musfirah, N. H 2018. Struktur Komunitas Bulu Babi (Echinoidea) yang berasosiasi dengan Ekosistem Lamun di Pulau Barrang Lompo, Provinsi Sulawesi Selatan. Skripsi Program Studi Manajemen Sumberdaya Perairan Jurusan Perikanan Fakultas Ilmu Kelautan dan Perikanan Universitas Hasanuddin Makassar. 68 hal.

Nontji, A. 2005. Laut Nusantara. Edisi revisi. Penerbit Djembatan, Jakarta.

Odum, E. P. 1996 . Dasar-Dasar Ekologi: edisi ketiga. Yogyakarta : Gadja Mada University Press.

Rachmawaty. 2004. Studi penyebaran dan kepadatan Bulu Babi (Tripneustes gratilla) pada padang lamun di perairan Pantai Desa Atowatu Kecamatan Soropia Kabupaten Kendari peroide II (Juni-Agustus 2003). [Skripsi]. Kendari :. Universitas Haluoleo.

Radjab, A.W 2001. Reproduksi dan siklus hidup bulu babi. Oseana 26(3): 25-36. 36. Permonde, Sulawesi Selatan. Jakarta : Badan Riset Kelautan dan Perikanan, Departemen Kelautan dan Perikanan.

Setiawan F (2010). Panduan Lapangan Identifikasi Ikan Karang dan Invertebrata Laut dilengkapi Dengan Metode Monitoringnya. Wildlife Conservation Society (WCS).

Suryanti dan C. A'in. 2013. Perbedaan Kelimpahan Bulu Babi (Sea Urchin) pada Substrat yang Berbeda di Legon Boyo Karimunjawa Jepara. Prosiding SEMNAS Ke III.Hasil-hasil Perikanan dan Kelautan. FPIK . UNDIP. Semarang. ISSN 2339-0833. 4:165172.

Suryanti dan Ruswahyuni. 2014. Perbedaan Kelimpahan Bulu Babi (Echinoidea) pada Ekosistem Karang dan Lamun di Pancuran Belakang, Karimunjawa Jepara.
Jurnal Saintek Perikanan 10(1): 62-67.

Wibisono, D. 2005. Metode Penelitian \& Analisis Data. Jakarta: Salemba Medika. 